Author affiliations appear at the end of this article.

Published online ahead of print at www.jco.org on August 17, 2015. Written on behalf of the CAPP2 Consortium.

Original intervention study was supported by grants from Medical Research Council (No. G0100496), Cancer Research UK (Nos. C1297/A5013 and C588/A4994), European Union (No. PL96/3694), Cancer Council Victoria (Australia), Technology and Human Resources for Industry Programme-South Africa, Sigrid Juselius Foundation, and Finnish Cancer Foundation. After completion of study design and choice of interventions, Bayer and National Starch and Chemical provided free interventions (active agent and matched placebo), including cost of packaging, and made donations to Newcastle University to help cover cost of administration and distribution of intervention agents. CAPP2 (Current Controlled Trials No. ISRCTN59521990) was academic collaboration

Terms in blue are defined in the glossary, found at the end of this article and online at www.jco.org.

Presented at British Society for Genetic Medicine Conference, Liverpool, United Kingdom, September 22-24, 2014.

Authors' disclosures of potential conflicts of interest are found in the article online at www.jco.org. Author contributions are found at the end of this article.

Corresponding author: John C. Mathers, PhD, Human Nutrition Research Centre, Institute of Cellular Medicine, Campus for Ageing and Vitality, Newcastle University, Newcastle upon Tyne, NE4 5PL, United Kingdom; e-mail: john.mathers@ncl.ac.uk.

() 2015 by American Society of Clinical Oncology

0732-183X/15/3331w-3591w/\$20.00

DOI: 10.1200/JCO.2014.58.9952

\title{
Obesity, Aspirin, and Risk of Colorectal Cancer in Carriers of Hereditary Colorectal Cancer: A Prospective Investigation in the CAPP2 Study
}

Mohammad Movahedi, D. Timothy Bishop, Finlay Macrae, Jukka-Pekka Mecklin, Gabriela Moeslein, Sylviane Olschwang, Diana Eccles, D. Gareth Evans, Eamonn R. Maher, Lucio Bertario, Marie-Luise Bisgaard, Malcolm G. Dunlop, Judy W.C. Ho, Shirley V. Hodgson, Annika Lindblom, Jan Lubinski, Patrick J. Morrison, Victoria Murday, Raj S. Ramesar, Lucy Side, Rodney J. Scott, Huw J.W. Thomas, Hans F. Vasen, John Burn, and John C. Mathers

Listen to the podcast by Dr Meyerhardt at www.jco.org/podcasts

$$
\begin{array}{llllllll}
\text { A } & \text { B } & \text { S } & \text { T } & \text { R } & \text { A } & \text { C } & \text { T }
\end{array}
$$

\section{Purpose}

In the general population, increased adiposity is a significant risk factor for colorectal cancer (CRC), but whether obesity has similar effects in those with hereditary CRC is uncertain. This prospective study investigated the association between body mass index and cancer risk in patients with Lynch syndrome (LS).

\section{Patients and Methods}

Participants with LS were recruited to the CAPP2 study, in which they were randomly assigned to receive aspirin $600 \mathrm{mg}$ per day or aspirin placebo, plus resistant starch $30 \mathrm{~g}$ per day or starch placebo $(2 \times 2$ factorial design). Mean intervention period was 25.0 months, and mean follow-up was 55.7 months.

\section{Results}

During follow-up, 55 of 937 participants developed CRC. For obese participants, CRC risk was $2.41 \times(95 \%$ $\mathrm{Cl}, 1.22$ to 4.85 ) greater than for underweight and normal-weight participants (reference group), and CRC risk increased by $7 \%$ for each $1-\mathrm{kg} / \mathrm{m}^{2}$ increase in body mass index. The risk of all LS-related cancers in obese people was $1.77 \times(95 \% \mathrm{Cl}, 1.06$ to $2.96 ; P=.03)$ greater than for the reference group. In subgroup analysis, obesity was associated with $3.72 \times(95 \% \mathrm{Cl}, 1.41$ to 9.81$)$ greater CRC risk in patients with LS with MLH1 mutation, but no excess risk was observed in those with $M S H 2$ or MSH6 mutation $(P=.5)$. The obesity-related excess $\mathrm{CRC}$ risk was confined to those randomly assigned to the aspirin placebo group (adjusted hazard ratio, 2.75; $95 \% \mathrm{Cl}, 1.12$ to $6.79 ; P=.03$ ).

\section{Conclusion}

Obesity is associated with substantially increased CRC risk in patients with LS, but this risk is abrogated in those taking aspirin. Such patients are likely to benefit from obesity prevention and/or regular aspirin.

\section{J Clin Oncol 33:3591-3597. (C) 2015 by American Society of Clinical Oncology}

\section{INTRODUCTION}

Lynch syndrome (LS; also known as hereditary nonpolyposis colon cancer) is an autosomaldominant disease and the commonest cause of hereditary bowel cancer. LS is caused by germline pathogenic variants in DNA mismatch repair (MMR) genes MLH1, MSH2, MSH6, and PMS2. Despite the high penetrance of this condition, treatment with aspirin (600 mg per day for mean of 25 months) halved cancer incidence in LS carriers after a mean of 55.7 months. ${ }^{1}$ This finding suggests that cancer development in LS may be modulated by exposures, especially those influencing inflammation.

There is substantial evidence that adults with higher adiposity are at greater risk of several common cancers, including colorectal cancer (CRC). ${ }^{2,3}$ A recent systematic review and meta-analysis identified 41 prospective studies of obesity and 13 studies of central obesity (measured as waist circumference) involving approximately 9 million individuals and 92,481 patient cases of CRC. Overall, the relative risk (RR) of CRC for those in the obese versus normalweight category was 1.33 ( $95 \%$ CI, 1.25 to 1.42 ); RR for those in the highest versus lowest category of WC 
was 1.46 (95\% CI, 1.33 to 1.56$).{ }^{4}$ There was no evidence of publication bias, and the positive association with obesity was evident for both sexes, several geographic regions, and cancers of colon and rectum. ${ }^{4}$ In patients with LS, a prospective cohort study from the Netherlands

\begin{tabular}{|c|c|c|}
\hline Characteristic & $\begin{array}{c}\text { Colorectal } \\
\text { Adenoma } \\
\text { Data Set } \\
(n=746) \\
\text { No. }(\%)\end{array}$ & $\begin{array}{c}\text { Colorectal } \\
\text { Cancer } \\
\text { Data Set } \\
(n=937) \\
\text { No. }(\%)\end{array}$ \\
\hline Male sex & $336(45.0)$ & $412(44.0)$ \\
\hline \multicolumn{3}{|l|}{ Age at cohort entry, years } \\
\hline Mean & 45.2 & 45.2 \\
\hline SD & 10.8 & 11.0 \\
\hline Median & 44.9 & 44.9 \\
\hline Q1-Q3 & $36.7-53.2$ & $36.3-53.3$ \\
\hline \multicolumn{3}{|l|}{ Age quartile, years } \\
\hline $21.5-36.25$ & $179(24.0)$ & $234(25.0)$ \\
\hline $36.26-44.85$ & $192(25.7)$ & $234(25.0)$ \\
\hline $44.86-53.32$ & $191(25.6)$ & $234(25.0)$ \\
\hline$\geq 55.33$ & $184(24.7)$ & $235(25.0)$ \\
\hline \multicolumn{3}{|l|}{ Follow-up time, months } \\
\hline Mean & 28.0 & 55.7 \\
\hline SD & 11.2 & 31.2 \\
\hline Median & 25.0 & 53.1 \\
\hline Q1-Q3 & $23.4-30.3$ & $29.4-78.3$ \\
\hline \multicolumn{3}{|c|}{ Time receiving intervention, months } \\
\hline Mean & 29.0 & 25.0 \\
\hline SD & 11.5 & 13.4 \\
\hline Median & 25.3 & 24.4 \\
\hline Q1-Q3 & $23.7-33.5$ & $15.9-28.9$ \\
\hline \multicolumn{3}{|l|}{$\mathrm{BMI}, \mathrm{kg} / \mathrm{m}^{2}$} \\
\hline Mean & 25.8 & 25.9 \\
\hline SD & 4.7 & 4.8 \\
\hline Median & 25.1 & 25.2 \\
\hline Interquartile range & $22.5-28.2$ & $22.7-28.4$ \\
\hline \multicolumn{3}{|l|}{ BMI category, $\mathrm{kg} / \mathrm{m}^{2}$} \\
\hline Underweight (< 18.5) & $12(1.6)$ & $14(1.5)$ \\
\hline Normal weight (18.5-24.9) & $341(47.7)$ & $418(44.6)$ \\
\hline Overweight (25.0-29.9) & $254(34.1)$ & 321 (34.3) \\
\hline Obese $(\geq 30)$ & $112(15.1)$ & $143(15.3)$ \\
\hline Missing & $27(3.6)$ & $41(4.4)$ \\
\hline \multicolumn{3}{|l|}{ MMR gene mutation } \\
\hline Clinical diagnosis & $132(17.7)$ & $163(17.4)$ \\
\hline MLH1 & $358(48.0)$ & $464(49.5)$ \\
\hline $\mathrm{MSH} 2$ & 235 (31.5) & $284(30.3)$ \\
\hline MSH6 & $21(2.82)$ & $26(2.8)$ \\
\hline \multicolumn{3}{|c|}{ Clinical center (geographic region) } \\
\hline Northern Europe & 334 (44.8) & $423(45.1)$ \\
\hline United Kingdom & $218(29.2)$ & 277 (29.6) \\
\hline Other & $194(26.0)$ & 237 (25.3) \\
\hline \multicolumn{3}{|l|}{ Intervention } \\
\hline \multicolumn{3}{|l|}{ Aspirin } \\
\hline Placebo & $343(46.0)$ & $434(46.3)$ \\
\hline Aspirin & $350(46.9)$ & $427(45.6)$ \\
\hline Not randomly assigned & $53(7.1)$ & $76(8.1)$ \\
\hline \multicolumn{3}{|l|}{ Resistant starch } \\
\hline Placebo & 369 (49.5) & 455 (48.6) \\
\hline Resistant starch & $358(48.0)$ & $463(49.4)$ \\
\hline Not randomly assigned & $19(2.5)$ & $19(2.0)$ \\
\hline
\end{tabular}

found that compared with normal weight, there was a statistically significant association between overweight (body mass index [BMI] $\geq 25 \mathrm{~kg} / \mathrm{m}^{2}$ ) and colorectal adenoma (benign precursor of CRC) risk in men but not in women. ${ }^{5}$ These findings are in line with an earlier Canadian case-control study, which reported that men with and without clinically defined familial risk of cancer (LS diagnosed using Amsterdam ${ }^{6}$ or Bethesda ${ }^{7}$ criteria) were at significantly greater CRC risk if overweight $\left(\mathrm{BMI} \geq 25 \mathrm{~kg} / \mathrm{m}^{2}\right)$ or obese $\left(\mathrm{BMI} \geq 30 \mathrm{~kg} / \mathrm{m}^{2}\right)$ compared with normal weight. ${ }^{8}$ As in the Dutch study, there was no relationship between adiposity and LS-related bowel cancer in women. ${ }^{8}$ In addition, a retrospective analysis of data from participants in the National Cancer Institute Colon Cancer Family Registry with germline MMR mutation showed that increased BMI at age 20 years was associated with subsequent higher CRC risk. ${ }^{9}$

\begin{tabular}{|c|c|c|}
\hline Variable & $\begin{array}{l}\text { Unadjusted HR } \\
\text { HR (95\% CI) }\end{array}$ & $\begin{array}{l}\text { Adjusted HR* } \\
\text { HR }(95 \% \mathrm{Cl})\end{array}$ \\
\hline \multicolumn{2}{|l|}{ Participants with adenoma of total } & 117 of 719 \\
\hline $\begin{array}{l}\mathrm{BMI}, \mathrm{kg} / \mathrm{m}^{2} \text { (continuous variable } \\
\text { HR per unit BMI) }\end{array}$ & BMI, $\mathrm{kg} / \mathrm{m}^{2}$ (continuous variable & 1.02 (0.98 to 1.06$)$ \\
\hline $\begin{array}{l}\text { Under- and normal weight } \\
(<25)\end{array}$ & 1.00 & 1.00 \\
\hline Overweight (25-29.99) & 1.05 (0.70 to 1.58$)$ & 0.98 (0.65 to 1.48$)$ \\
\hline Obese $(\geq 30)$ & $1.39(0.85$ to 2.29$)$ & 1.28 (0.77 to 2.12$)$ \\
\hline Women & 56 of 389 & 56 of 389 \\
\hline $\begin{array}{l}\mathrm{BMI}, \mathrm{kg} / \mathrm{m}^{2} \text { (continuous } \\
\text { variable) }\end{array}$ & 1.04 (0.99 to 1.08 ) & 1.03 (0.99 to 1.07$)$ \\
\hline $\begin{array}{l}\text { Under- and normal weight } \\
(<25)\end{array}$ & 1.00 & 1.00 \\
\hline Overweight (25-29.99) & $1.18(0.65$ to 2.16$)$ & 1.23 (0.66 to 2.28$)$ \\
\hline Obese $(\geq 30)$ & 1.46 (0.73 to 2.93$)$ & 1.38 (0.67 to 2.83 ) \\
\hline Men & 61 of 330 & 61 of 330 \\
\hline $\begin{array}{l}\mathrm{BMI}, \mathrm{kg} / \mathrm{m}^{2} \text { (continuous } \\
\text { variable) }\end{array}$ & 0.99 (0.93 to 1.07$)$ & 0.99 (0.93 to 1.07$)$ \\
\hline $\begin{array}{l}\text { Under- and normal weight } \\
(<25)\end{array}$ & 1.00 & 1.00 \\
\hline Overweight (25-29.99) & 0.89 (0.51 to 1.55$)$ & 0.82 (0.47 to 1.46$)$ \\
\hline Obese $(\geq 30)$ & $1.24(0.61$ to 2.51$)$ & 1.17 (0.56 to 2.43 ) \\
\hline MLH1 mutation & 55 of 339 & 55 of 339 \\
\hline $\begin{array}{l}\text { Under- and normal weight } \\
(<25)\end{array}$ & 1.00 & 1.00 \\
\hline Overweight (25-29.99) & $0.70(0.38$ to 1.29$)$ & 0.67 (0.36 to 1.25$)$ \\
\hline Obese $(\geq 30)$ & 1.25 (0.59 to 2.65$)$ & $1.21(0.55$ to 1.11$)$ \\
\hline MSH2 mutation & 30 of 232 & 30 of 232 \\
\hline $\begin{array}{l}\text { BMI, } \mathrm{kg} / \mathrm{m}^{2} \text { (continuous } \\
\text { variable) }\end{array}$ & 1.04 (0.96 to 1.12$)$ & $1.02(0.94$ to 1.11$)$ \\
\hline $\begin{array}{l}\text { Under- and normal weight } \\
(<25)\end{array}$ & 1.00 & 1.00 \\
\hline Overweight (25-29.99) & 0.76 (0.31 to 1.86$)$ & 0.64 (0.25 to 1.62$)$ \\
\hline Obese $(\geq 30)$ & $1.64(0.70$ to 3.88$)$ & 1.29 (0.53 to 3.15$)$ \\
\hline Clinical diagnosis & 30 of 127 & 30 of 127 \\
\hline $\begin{array}{l}\mathrm{BMI}, \mathrm{kg} / \mathrm{m}^{2} \text { (continuous } \\
\text { variable) }\end{array}$ & $1.04(0.99$ to 1.10$)$ & 1.04 (0.99 to 1.10$)$ \\
\hline $\begin{array}{l}\text { Under- and normal weight } \\
(<25)\end{array}$ & 1.00 & 1.00 \\
\hline Overweight (25-29.99) & $2.32(1.03$ to 5.20$) \dagger$ & $2.53(1.10$ to 5.83$) \dagger$ \\
\hline Obese $(\geq 30)$ & $1.17(0.40$ to 3.45$)$ & 1.32 (0.42 to 4.13$)$ \\
\hline $\begin{array}{l}\text { Abbreviations: BMI, body mass ind } \\
\text { *Adjusted for age, starch, aspirin, } \\
\text { and sex, where appropriate. } \\
\text { tSignificant at } P=.02 \text {. }\end{array}$ & $\begin{array}{l}\text {; HR, hazard ratio; } \\
\text { ographic region, mi }\end{array}$ & $\begin{array}{l}\text { S, Lynch syndrome. } \\
\text { ismatch repair gene, }\end{array}$ \\
\hline
\end{tabular}


Several plausible mechanisms link higher adiposity with greater CRC risk, including those that cause genomic damage (eg, inflammation and oxidative stress), those that promote cell proliferation (eg, raised concentrations of insulin-like growth factors), and those that affect immunosurveillance. ${ }^{10,11}$ In addition, the gut microbiome may mediate both increased adiposity and greater CRC risk. ${ }^{12,13}$ Our hypothesis is that because of their reduced ability to combat DNA damage, overweight or obese patients with LS may be at enhanced cancer risk compared with normal-weight patients with LS. We aimed to test that hypothesis in a prospective study of patients with LS who were enrolled onto the CAPP2 (Colorectal Adenoma/Carcinoma Prevention Programme 2) study, a randomized controlled trial of effects of intervention with aspirin and/or resistant starch (RS) using a $2 \times 2$ factorial design. ${ }^{1,14,15}$

\section{PATIENTS AND METHODS}

Between January 1999 and March 2005, 937 LS carriers started intervention in the CAPP2 study. ${ }^{14,16}$ Eligible patients were proven carriers of DNA MMR mutation or members of a family that met the Amsterdam diagnostic criteria ${ }^{6}$ and had a personal history of a cured LS neoplasm but an intact colon. Eligible participants (in 43 centers across 16 countries) were randomly assigned separately in a factorial design to aspirin $600 \mathrm{mg}$ per day and/or RS $30 \mathrm{~g}$ per day, with placebo controls. The primary end point was the incidence of bowel neoplasia. The number, size, and histologic status of all colonic adenomas and carcinomas were recorded and compared between treatment and placebo groups. ${ }^{14}$ The intervention period lasted a mean of 25.0 months (median, 24.4; quartile [Q] 1 to Q3, 15.9 to 28.9 months), and the study had a preplanned design for 10-year follow-up. At the time of our analysis, the earliest enrolled participants had reached the 10-year threshold, and mean follow-up was 55.7 months (median, 53.1; Q1 to Q3, 29.4 to 78.3 months). ${ }^{1}$

Cancer incidence analysis focused on follow-up of the 937 patients in whom cancer outcome data were recorded from their date of entry into the CAPP2 study until the last known date for which the local center had information with respect to cancer diagnosis. Adenoma incidence was recorded in detail for 746 participants who completed the intervention phase of the study. Outside this group, and beyond the intervention, adenoma incidence was only partially recorded and was excluded from our analysis. At recruitment, participants were asked height and weight. Participant adiposity was determined using the WHO criteria for BMI categories (ie, underweight, $<18.5$; normal weight, 18.5 to 24.99 ; overweight, 25 to 29.99 ; and obese, $\left.\geq 30 \mathrm{~kg} / \mathrm{m}^{2}\right) .{ }^{17}$ For analysis purposes in this study, BMI was treated as a quantitative trait, although for clarity, categorical results are also provided, in which the underweight $(\mathrm{n}=14)$ and normal-weight groups $(\mathrm{n}=418)$ were combined (BMI $\leq$ $\left.24.99 \mathrm{~kg} / \mathrm{m}^{2}\right)$ as the reference group.

\section{Statistical Analysis}

The analysis was based on time to first event using life-table methods and Cox proportional hazards. The life-table analysis used the end of follow-up for each participant as the time of first event, if affected; for those unaffected, the last recorded contact date at which the clinical status of the participant was known was used. The analysis considered the following events: adenoma occurrence (this analysis considered data from intervention time period only); CRC incidence during both intervention and follow-up phases (those without diagnosis of CRC were considered unaffected at this last clinical contact); and LS cancer (same as for CRC incidence but including all cancers within syndrome). The analysis strategy was designed to test the hypothesis that BMI increases the risk of neoplasia in those with LS. Cox proportional hazards models were used to estimate crude and adjusted hazard ratios (HRs) and 95\% CIs for the association between BMI and risk of LS-related neoplasia (adenoma and cancer), adjusting for age, sex, geographic region, MMR gene mutation, and intervention (aspirin or RS). The analyses were repeated for sex and MMR gene mutation subgroups separately. All analyses used STATA software (version 10; STATA, College Station, TX).

\section{RESULTS}

Table 1 summarizes the baseline characteristics for participants with LS in the CAPP2 study. The median age at study entry was 44.9 years (Q1 to Q3, 36 to 53 years) in both adenoma and CRC data sets. Women made up 55\% and 56\% of participants in the adenoma and

Table 3. HRs for Developing Cancer by BMI Category Stratified by Sex in Participants With LS

\begin{tabular}{|c|c|c|c|}
\hline Participants with cancer diagnosis of total participants with follow-up & 54 of 896 & 43 of 896 & 95 of 896 \\
\hline $\mathrm{BMI}, \mathrm{kg} / \mathrm{m}^{2}$ (quantitative variable) & $1.07(1.02$ to 1.13$) \dagger$ & 1.02 (0.96 to 1.08$)$ & $1.05(1.01$ to 1.09$) \ddagger$ \\
\hline Under- and normal weight $(<25)$ & 1.00 & 1.00 & 1.00 \\
\hline Overweight (25-29.99) & 1.09 (0.57 to 2.11$)$ & $0.59(0.26$ to 1.31$)$ & $0.87(0.53$ to 1.44$)$ \\
\hline Women & 25 of 494 & 36 of 494 & 60 of 494 \\
\hline $\mathrm{BMI}, \mathrm{kg} / \mathrm{m}^{2}$ (quantitative variable) & 1.06 (0.99 to 1.13$)$ & $1.03(0.97$ to 1.09$)$ & 1.04 (0.99 to 1.09$)$ \\
\hline Under- and normal weight $(<25)$ & 1.00 & 1.00 & 1.00 \\
\hline Overweight (25-29.99) & 0.66 (0.20 to 2.13$)$ & 0.80 (0.33 to 1.93$)$ & $0.74(0.37$ to 1.50$)$ \\
\hline Obese $(\geq 30)$ & 2.36 (0.91 to 6.20$)$ & 1.58 (0.68 to 3.66$)$ & 1.77 (0.93 to 3.37$)$ \\
\hline Men & 29 of 402 & 7 of 402 & 35 of 402 \\
\hline \multicolumn{4}{|c|}{$\begin{array}{l}\text { Abbreviations: } \mathrm{BMI} \text {, body mass index; } \mathrm{CRC} \text {, colorectal cancer; } \mathrm{HR} \text {, hazard ratio; LS, Lynch syndrome. } \\
\text { *Adjusted for age, starch, aspirin, geographic region, mismatch repair gene, and sex, where appropriate. } \\
\text { tSignificant at } P=.007 . \\
\text { tSignificant at } P=.02 \\
\text { §Significant at } P=.03\end{array}$} \\
\hline
\end{tabular}


cancer data sets, respectively. In both data sets, approximately $80 \%$ of participants had mutation in $M L H 1$ or $M S H 2,34 \%$ were overweight, and $15 \%$ were obese $\left(\mathrm{BMI} \geq 30 \mathrm{~kg} / \mathrm{m}^{2}\right.$; Table 1$)$.

\section{Obesity and Risk of Colorectal Adenoma}

Of 719 people (of 746 who completed exit colonoscopy from intervention study) for whom BMI data were available, 117 developed colorectal adenoma during the intervention phase (median, 25.3 months; Table 2). Overall, there was a nonsignificant increased risk for colorectal adenoma among obese participants (HR, 1.28; 95\% CI, 0.77 to 2.12) compared with the reference group (HR adjusted for age, sex, aspirin and RS intake, geographic region, and MMR gene status; Table 2). A nonsignificant increased risk in obese participants was found for both men (HR, 1.17;95\% CI, 0.56 to 2.43) and women (HR, 1.38; 95\% CI, 0.67 to 2.83 ) and for both $M L H 1$ (HR, 1.21; 95\% CI, 0.55 to 2.63 ) and $\mathrm{MSH} 2$ (HR, 1.29; 95\% CI, 0.53 to 3.15 ) gene mutation carriers.

\section{Obesity and Risk of CRC}

During longer-term follow-up (median, 53.1 months), 55 of the 937 participants in the CAPP2 study developed CRC (Table 3; BMI data were not available for one patient with CRC). Risk of CRC development was $9 \%$ higher in the overweight compared with reference group, but the effect was not statistically significant (HR, 1.09; 95\% CI, 0.57 to $2.11 ; P=.8)$. However, for obese participants, CRC risk was $2.34 \times(95 \% \mathrm{CI}, 1.17$ to $4.67 ; P=.02)$, and significantly, greater than for the reference group (HR adjusted for age, sex, aspirin and RS intake, geographic region, and MMR gene status; Table 3; Fig 1A). When the analysis was conducted for each sex separately, CRC risk was $2.41 \times(95 \% \mathrm{CI}, 0.85$ to 6.81$)$ and $2.36 \times(95 \% \mathrm{CI}, 0.91$ to 6.20) greater for obese men and women, respectively, than for the corresponding reference group. With BMI as a continuous variable, CRC risk increased significantly with each unit of BMI in men (HR, 1.12 ; $95 \% \mathrm{CI}, 1.02$ to $1.24 ; P=.02$ ) but was marginally weaker in women (HR, 1.06; 95\% CI, 0.99 to $1.13 ; P=.09$ ). There was no statistically significant interaction between sex and BMI category in CRC risk ( $\operatorname{LR} \chi^{2}$ with $2 d f, 1.37 ; P=.24$; data not shown).

The adjusted HRs for the associations between BMI and CRC risk stratified by MMR gene mutation are listed in Table 4. Obese participants with $M L H 1$ gene mutation had significantly higher CRC risk compared with the reference group (HR, 3.72; 95\% CI, 1.41 to 9.81; $P=.008)$. In contrast, CRC risk was not raised significantly in obese participants with $\mathrm{MSH} 2$ mutation (HR, 1.59; 95\% CI, 0.47 to 5.44).

\section{Obesity and Risk of LS-Related Cancers}

The secondary analysis considered all LS-related cancers and non-CRC LS cancers, including endometrial, ovarian, and pancreatic cancers and cancers of the brain, small bowel, gallbladder, ureter, stomach, and kidney. ${ }^{18}$ After adjustment, there were no significant associations between BMI category and risk of non-CRC LS cancers for men, women, or all participants (Table 3). In addition, there were no significant adjusted associations between BMI category and risk of other LS cancers when stratified by MMR gene mutation (Table 4). Details of individual LS cancer incidence in this study have been reported by Burn et al. ${ }^{1}$

When CRC was included with all other LS cancers, obesity was a significant risk factor for all LS-related cancer incidence (HR, 2.18; 95\% CI, 1.33 to $3.58 ; P=.002)$. This effect remained significant $(\mathrm{HR}$, $1.81 ; 95 \% \mathrm{CI}, 1.08$ to $3.03 ; P=.03$ ) after adjusting for other variables

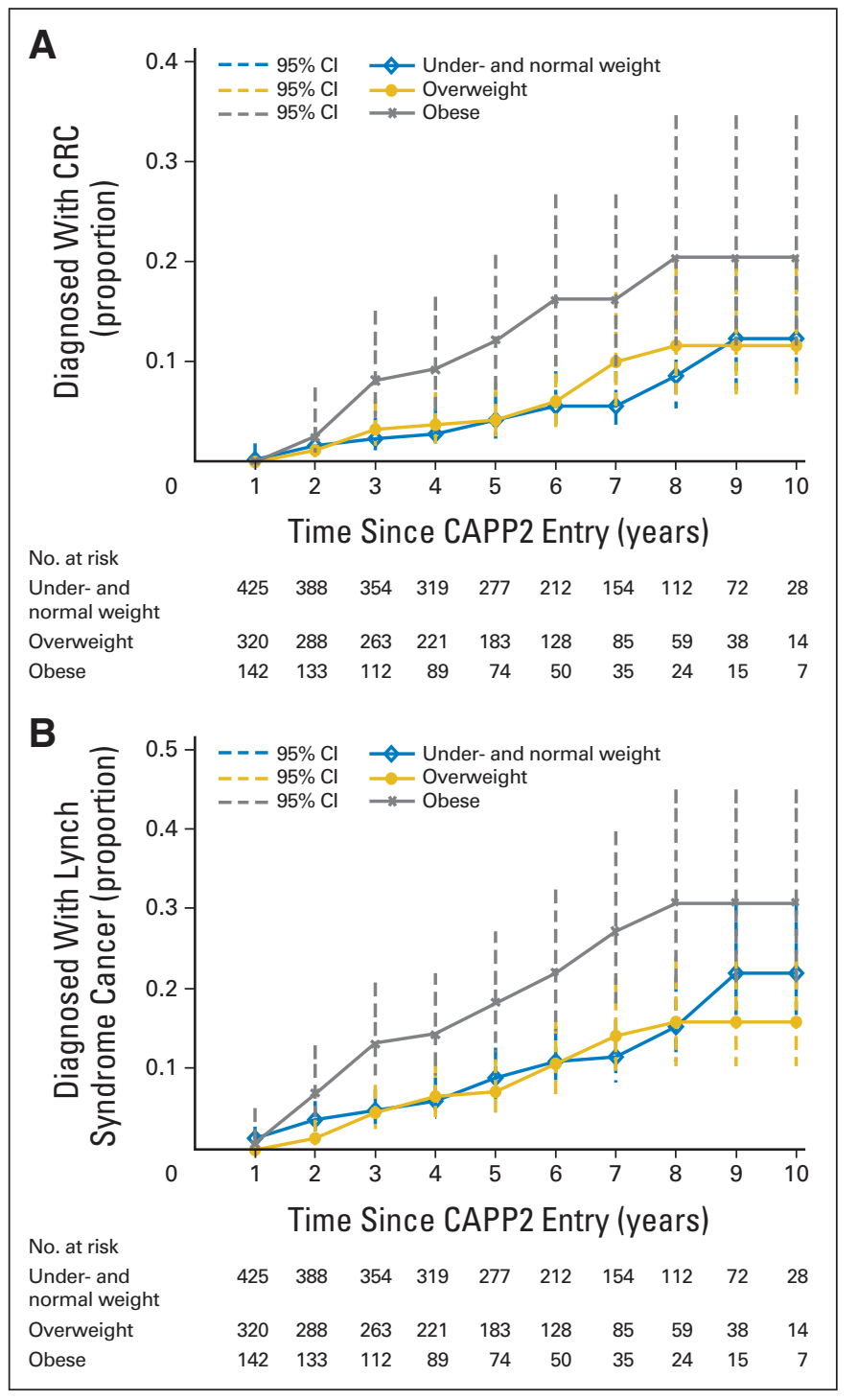

Fig 1. Time to first $(A)$ colorectal cancer $(C R C)$ and $(B)$ Lynch syndrome cancer in participants stratified by body mass index category.

(age, sex, aspirin and RS intake, geographic region, and MMR gene; Table 3; Fig 1B). In addition, among $M L H 1$ gene mutation carriers, obesity increased the risk of all LS-related cancers (HR, 2.77; 95\% CI, 1.39 to $5.52 ; P=.004)$, but this association became nonsignificant after adjustment for all covariates (HR, 1.76; 95\% CI, 0.85 to 3.65; Table 4).

\section{Effects of Aspirin}

Given the evidence that aspirin treatment reduces cancer risk in patients with LS, we carried out separate analyses of effects of BMI among those randomly assigned to aspirin and those to aspirin placebo in the CAPP2 study (Table 5). In patients with LS randomly assigned to placebo, there was a significant association between increased BMI and CRC risk ( $\mathrm{HR}, 1.10 ; 95 \% \mathrm{CI}, 1.03$ to $1.17 ; P=.001)$, whereas there was no evidence of an increased risk among those randomly assigned to aspirin (HR, 1.00 ; $95 \% \mathrm{CI}, 0.90$ to 1.12 ; nonsignificant). Indeed, these two effect sizes are significantly different $(P=$ 


\begin{tabular}{|c|c|c|c|}
\hline Variable & $\begin{array}{c}\text { CRC Incidence } \\
\text { Adjusted HR }(95 \% \mathrm{CI})^{*}\end{array}$ & $\begin{array}{l}\text { Incidence of Other LS-Related } \\
\text { Cancers (excluding CRC) } \\
\text { Adjusted HR }(95 \% \mathrm{Cl})^{*}\end{array}$ & $\begin{array}{c}\text { Incidence of All } \\
\text { LS-Related Cancers } \\
\text { Adjusted HR (95\% Cl)* }\end{array}$ \\
\hline MLH1 mutation & 28 of 438 & 22 of 438 & 50 of 438 \\
\hline $\mathrm{BMI}, \mathrm{kg} / \mathrm{m}^{2}$ (quantitative variable) & $1.12(1.04$ to 1.21$) \dagger$ & 0.95 (0.86 to 1.05$)$ & 1.05 (0.99 to 1.12$)$ \\
\hline Under- and normal weight $(<25)$ & 1.00 & 1.00 & 1.00 \\
\hline Overweight (25-29.99) & 1.19 (0.47 to 3.01$)$ & $0.39(0.13$ to 1.14$)$ & 0.75 (0.37 to 1.48$)$ \\
\hline Obese $(\geq 30)$ & $3.72(1.41$ to 9.81$) \neq$ & 0.64 (0.19 to 2.19$)$ & 1.76 (0.85 to 3.65$)$ \\
\hline $\mathrm{MSH} 2$ mutation & 20 of 276 & 16 of 276 & 35 of 276 \\
\hline $\mathrm{BMI}, \mathrm{kg} / \mathrm{m}^{2}$ (quantitative variable) & 1.01 (0.91 to 1.12$)$ & $1.09(1.00$ to 1.20$) \S$ & 1.04 (0.97 to 1.11$)$ \\
\hline Under- and normal weight $(<25)$ & 1.00 & 1.00 & 1.00 \\
\hline Overweight (25-29.99) & $1.26(0.44$ to 3.60$)$ & 1.21 (0.30 to 4.92$)$ & 1.33 (0.58 to 3.06$)$ \\
\hline Obese $(\geq 30)$ & 1.59 (0.47 to 5.44$)$ & $4.34(1.15$ to 16.4$)$ & 2.02 (0.84 to 4.85$)$ \\
\hline \multicolumn{4}{|c|}{$\begin{array}{l}\text { Abbreviations: BMI, body mass index; CRC, colorectal cancer; HR, hazard ratio; LS, Lynch syndrome; MMR, mismatch repair. } \\
\text { *Adjusted for age, sex, starch, aspirin, and geographic region. } \\
\text { tSignificant at } P=.002 . \\
\text { ‡Significant at } P=.008 \\
\text { §Significant at } P=.05\end{array}$} \\
\hline
\end{tabular}

$.01)$, suggesting that aspirin changes the relationship between BMI and CRC risk, with no evidence of any association for those receiving aspirin.

\section{DISCUSSION}

In this prospective study, we observed a statistically significant positive association between BMI at baseline and subsequent CRC risk in participants with LS. Those who were obese had $2.34 \times(95 \%$ CI, 1.17 to 4.67$)$ greater risk of CRC $(P=.02)$ than those of normal weight, and there was a linear increase in HR for CRC with increasing BMI. The greater CRC risk associated with each $1-\mathrm{kg} / \mathrm{m}^{2}$ increase in BMI seemed to be stronger for men (HR, 1.12; 95\% CI, 1.02 to $1.24 ; P=.02$ ) than for women (HR, $1.06 ; 95 \% \mathrm{CI}, 0.99$ to 1.13 ; Table 3 ), although this difference was not statistically significant. This seemingly sex-specific relationship between adiposity and colorectal neoplasia among patients with LS is consistent with previous observations (Appendix Table A1, online only). In a case-control study, Campbell et $\mathrm{al}^{8}$ reported significantly greater CRC risk in obese men, but not women, with a clinical diagnosis of LS. Similarly, in a short-term prospective study (median follow-up, 20 months) of those with no previous colorectal neoplasia, Botma et $\mathrm{al}^{5}$ observed that the risk of colorectal adenomatous polyps was increased significantly in overweight and obese men, but not women, who carried germline mutations in MMR genes. In the CAPP2 study, the increased cancer risk with increased $\mathrm{BMI}$ in men but not women was restricted to the colorectum (Table 3 ).

There is substantial evidence that greater adiposity is associated with higher CRC risk in the general population. A recent metaanalysis of 41 prospective studies involving approximately 9 million participants and 85,935 patient cases of CRC revealed an overall RR of 1.33 (95\% CI, 1.25 to 1.42 ) in those in the obese versus normal BMI category. ${ }^{4}$ When stratified by sex, CRC risk among obese participants was greater in men (RR, 1.47; 95\% CI, 1.36 to 1.58 ) than in women (RR, $1.15 ; 95 \%$ CI, 1.08 to 1.23$){ }^{4}$ This observation of sex-dependent

\begin{tabular}{|c|c|c|c|}
\hline Variable & $\begin{array}{c}\text { CRC Incidence } \\
\text { Adjusted HR }(95 \% \mathrm{Cl})^{*}\end{array}$ & $\begin{array}{l}\text { Incidence of Other LS-Related } \\
\text { Cancers (excluding CRC) } \\
\text { Adjusted HR }(95 \% \mathrm{Cl})^{*}\end{array}$ & $\begin{array}{c}\text { Incidence of All } \\
\text { LS-Related Cancers } \\
\text { Adjusted HR (95\% Cl)* }\end{array}$ \\
\hline Placebo & 36 of 485 & 28 of 485 & 62 of 485 \\
\hline $\mathrm{BMI}, \mathrm{kg} / \mathrm{m}^{2}$ (quantitative variable) & $1.10(1.03$ to 1.17$) \dagger$ & 1.03 (0.96 to 1.10$)$ & $1.06(1.02$ to 1.11$) \ddagger$ \\
\hline Under- and normal weight $(<25)$ & 1.00 & 1.00 & 1.00 \\
\hline Overweight (25-29.99) & 1.46 (0.63 to 3.78 ) & 0.46 (0.16 to 1.29 ) & 0.91 (0.49 to 1.70$)$ \\
\hline Obese $(\geq 30)$ & $2.75(1.12$ to 6.75$) \S$ & 1.33 (0.51 to 3.52 ) & 1.91 (1.00 to 3.69$) \|$ \\
\hline Aspirin & 18 of 411 & 15 of 411 & 33 of 411 \\
\hline $\mathrm{BMI}, \mathrm{kg} / \mathrm{m}^{2}$ (quantitative variable) & 1.00 (0.90 to 1.12 ) & 0.99 (0.89 to 1.10$)$ & 1.00 (0.93 to 1.08$)$ \\
\hline Under- and normal weight $(<25)$ & 1.00 & 1.00 & 1.00 \\
\hline Overweight (25-29.99) & 0.74 (0.22 to 3.46$)$ & 0.89 (0.21 to 3.77$)$ & $0.87(0.36$ to 2.10$)$ \\
\hline Obese $(\geq 30)$ & 2.00 (0.61 to 6.70$)$ & 1.14 (0.30 to 4.27$)$ & 1.58 (0.66 to 3.81$)$ \\
\hline
\end{tabular}

Abbreviations: BMI, body mass index; CRC, colorectal cancer; HR, hazard ratio; LS, Lynch syndrome.

*Adjusted for age, sex, starch, mismatch repair gene status, and geographic region.

tSignificant at $P=.001$.

‡Significant at $P=.006$

$\S$ Significant at $P=.03$

$\|$ Significant at $P=.05$. 
greater CRC risk among obese men in the general population accords with our current findings in patients with LS and with reports from other observational studies (Appendix Table A1, online only). In addition, in the general population, there is a positive dose-response relationship between BMI and CRC risk; for each $2-\mathrm{kg} / \mathrm{m}^{2}$ increase in BMI, CRC risk increased by $7 \%$ (95\% CI, 4\% to 10\%). ${ }^{19}$ Importantly, among those with LS in our study, each $1-\mathrm{kg} / \mathrm{m}^{2}$ increase in BMI was associated with $7 \%$ increased CRC risk (ie, greater adiposity in patients with LS was associated with twice the excess risk for CRC of that seen in general population).

The mechanism responsible for the greater cancer risk among obese patients with LS is not known. However, given the germline loss of DNA MMR capacity in LS, it may be hypothesized that adverse sequelae of greater body fatness (eg, chronic low-level inflammation) have a promoting effect on those stem cells that have accumulated DNA damage because of this dysfunctional repair system.

Up to $20 \%$ of unselected CRC tumors show microsatellite instability (MSI) - the cardinal feature of loss of MMR function - but in the vast majority of such tumors, the MMR dysfunction is the result of epigenetic silencing of the $M L H 1$ gene by promoter methylation. ${ }^{20}$ In a population-based case-control study, Slattery et $\mathrm{al}^{21}$ found that increased BMI was associated with greater risk of microsatellite-stable tumors but not of tumors exhibiting MSI. This observation is supported by findings from patients with stage II or III colon carcinoma participating in North Central Cancer Treatment Group and National Surgical Adjuvant Breast and Bowel Project adjuvant chemotherapy trials, where obesity was associated with a significantly lower rate of tumors showing deficient MMR. ${ }^{22}$ A more recent population-based case-control study reported that the risk of both microsatellite-stable and MSI-low, but not MSI-high, tumors increased significantly with increasing $\mathrm{BMI}^{23}$ In both of these studies, it is probable that MMR dysfunction in all, or most, CRC tumors was the result of somatic epigenetic-based loss of MMR; the tumorigenesis stage at which the loss occurred is unknown. In contrast, in LS, germline loss of MMR capacity drives tumorigenesis from the earliest stages, and it is possible that this early MMR dysfunction increases susceptibility to the tumorpromoting effects of greater adiposity. Interestingly, we found that CRC risk was increased significantly in obese patients with LS with germline mutation in $M L H 1$ (HR, 3.72; 95\% CI, 1.41 to $9.81 ; P=$ .008 ) but not in those with MSH2 mutation (Table 4). In the shortterm prospective study by Botma et $\mathrm{al},{ }^{5}$ there was a trend (not significant) toward a greater excess of adenomatous polyps in overweight and obese patients with LS with germline mutation in $M L H 1$ but not in $\mathrm{MSH} 2$ compared with those with BMI $<25 \mathrm{~kg} / \mathrm{m}^{2}$. A retrospective analysis of data from participants in the National Cancer Institute Colon Cancer Family Registry also found a significantly increased HR with increased BMI for MLH1 mutation carriers (HR, 1.36; 95\% CI, 1.04 to 1.77 ) but not for those with mutation in $\mathrm{MSH} 2, \mathrm{MSH}$, or PMS2. ${ }^{9}$ After recognition of DNA damage by a pair of MutS homologues, the MLH1 protein forms a heterodimer with PMS2, which leads to the initiation of MMR. ${ }^{24}$ Because all MMR proteins are necessary for successful DNA repair, the mechanistic basis for the seem- ingly greater susceptibility of $M L H 1$ mutation carriers to the adverse effects of obesity is not known.

Interestingly, our intervention study showed some evidence that the excess CRC risk in patients with LS is abrogated by regular aspirin consumption. Data from the Aspirin/Folate Polyp Prevention Study suggested that aspirin $325 \mathrm{mg}$ per day might be more effective in preventing advanced colorectal adenomas in those who are obese (RR, $0.44 ; 95 \% \mathrm{CI}, 0.17$ to 1.10 ) compared with normal-weight individuals (RR, 1.23 ; 95\% CI, 0.55 to 2.77 ), but the wide CIs precluded a definitive conclusion. ${ }^{25}$ In addition, a case-control study of women in the Australian National Endometrial Cancer Study reported that aspirin might reduce the risk of endometrial cancer among obese women. ${ }^{26}$

A limitation of our study is that height and weight (used for BMI estimation) were self-reported. It is well recognized that height and weight tend to be over- and underestimated, respectively, so absolute estimates of obesity can be underestimated. ${ }^{27}$ However, the sensitivity and specificity of self-reported height and weight in detecting obesity are good: 0.83 and 1.00 , respectively. ${ }^{27}$ This suggests that any errors in BMI estimation in our study were likely to result in conservative estimates of the association between obesity and increased cancer risk in patients with LS.

In summary, obesity is associated with greater risk of CRC in patients with LS. The excess risk of CRC with increasing adiposity was twice as great in patients with LS as has been observed by others for the general population. However, this increased CRC risk was significant in men only, and we observed that aspirin abrogated the excess cancer risk associated with obesity in patients with LS. These findings suggest that, in addition to recommended bowel surveillance, patients with LS are likely to benefit substantially from prevention-or effective treatment- of obesity and from regular aspirin use.

\section{AUTHORS' DISCLOSURES OF POTENTIAL CONFLICTS OF INTEREST}

Disclosures provided by the authors are available with this article at www.jco.org.

\section{AUTHOR CONTRIBUTIONS}

Conception and design: D. Timothy Bishop, Finlay Macrae, John Burn, John C. Mathers

Provision of study materials or patients: Jukka-Pekka Mecklin, Annika Lindblom, Rodney J. Scott

Collection and assembly of data: D. Timothy Bishop, Jukka-Pekka Mecklin, Gabriela Moeslein, Sylviane Olschwang, Diana Eccles, D. Gareth Evans, Eamonn R. Maher, Lucio Bertario, Marie-Luise Bisgaard, Malcolm G. Dunlop, Judy W.C. Ho, Shirley V. Hodgson, Annika

Lindblom, Jan Lubinski, Patrick J. Morrison, Victoria Murday, Raj S. Ramesar, Lucy Side, Rodney J. Scott, Huw J.W. Thomas, Hans F. Vasen, John Burn

Data analysis and interpretation: Mohammad Movahedi, D. Timothy Bishop, Finlay Macrae, John Burn, John C. Mathers

Manuscript writing: All authors

Final approval of manuscript: All authors

\section{REFERENCES}

1. Burn J, Gerdes AM, Macrae F, et al: Longterm effect of aspirin on cancer risk in carriers of hereditary colorectal cancer: An analysis from the
CAPP2 randomised controlled trial. Lancet 378 : 2081-2087, 2011

2. World Cancer Research Fund, American Institute for Cancer Research: Food, Nutrition, Physical Activity, and the Prevention of Cancer: A Global Perspective. Washingotn, DC, American Institute for Cancer Research, 2007

3. Kitahara CM, Berndt SI, de González AB, et al: Prospective investigation of body mass index, colorectal adenoma, and colorectal cancer in the prostate, lung, colorectal, and ovarian cancer screening trial. J Clin Oncol 31:2450-2459, 2013 
4. Ma $Y$, Yang $Y$, Wang $F$, et al: Obesity and risk of colorectal cancer: A systematic review of prospective studies. PloS ONE 8:e53916, 2013

5. Botma A, Nagengast FM, Braem MG, et al: Body mass index increases risk of colorectal adenomas in men with Lynch syndrome: The GEOLynch cohort study. J Clin Oncol 28:43464353, 2010

6. Vasen HF, Mecklin JP, Khan PM, et al: The International Collaborative Group on Hereditary NonPolyposis Colorectal Cancer (ICG-HNPCC). Dis CoIon Rectum 34:424-425, 1991

7. Umar A, Boland CR, Terdiman JP, et al: Revised Bethesda Guidelines for hereditary nonpolyposis colorectal cancer (Lynch syndrome) and microsatellite instability. J Natl Cancer Inst 96:261268, 2004

8. Campbell PT, Cotterchio M, Dicks E, et al: Excess body weight and colorectal cancer risk in Canada: Associations in subgroups of clinically defined familial risk of cancer. Cancer Epidemiol Biomarkers Prev 16:1735-1744, 2007

9. Win AK, Dowty JG, English DR, et al: Body mass index in early adulthood and colorectal cancer risk for carriers and non-carriers of germline mutations in DNA mismatch repair genes. $\mathrm{Br} \mathrm{J}$ Cancer 105:162-169, 2011

10. Ullman TA, Itzkowitz SH: Intestinal inflammation and cancer. Gastroenterology 140:1807-1816, 2011

11. Yehuda-Shnaidman E, Schwartz B: Mechanisms linking obesity, inflammation and altered metabolism to colon carcinogenesis. Obes Rev 13: 1083-1095, 2012
12. Le Chatelier E, Nielsen T, Qin J, et al: Richness of human gut microbiome correlates with metabolic markers. Nature 500:541-546, 2013

13. Smith PM, Howitt MR, Panikov $N$, et al: The microbial metabolites, short-chain fatty acids, regulate colonic Treg cell homeostasis. Science 341:569573,2013

14. Burn J, Bishop DT, Mecklin J-P, et al: Effect of aspirin or resistant starch on colorectal neoplasia in the Lynch syndrome. N Engl J Med 359:2567-2578, 2008

15. Mathers JC, Movahedi M, Macrae F, et al: Long-term effect of resistant starch on cancer risk in carriers of hereditary colorectal cancer: An analysis from the CAPP2 randomised controlled trial. Lancet Oncol 13:1242-1249, 2012

16. Liljegren A, Barker G, Elliott F, et al: Prevalence of adenomas and hyperplastic polyps in mismatch repair mutation carriers among CAPP2 participants: Report by the Colorectal Adenoma/ Carcinoma Prevention Programme 2. J Clin Oncol 26:3434-3439, 2008

17. World Health Organization: Global database on body mass index: BMI classification. http:// apps.who.int/bmi/index.jsp?introPage=intro_3.html

18. Vasen HF, Möslein G, Alonso A, et al: Guidelines for the clinical management of Lynch syndrome (hereditary non-polyposis cancer). J Med Genet 44:353-362, 2007

19. Moghaddam AA, Woodward M, Huxley R: Obesity and risk of colorectal cancer: A metaanalysis of 31 studies with 70,000 events. Cancer Epidemiol Biomarkers Prev 16:2533-2547, 2007

20. Cunningham JM, Kim CY, Christensen ER, et al: The frequency of hereditary defective mis- match repair in a prospective series of unselected colorectal carcinomas. Am J Hum Genet 69:780790, 2001

21. Slattery $M L$, Curtin $K$, Anderson $K$, et al: Associations between cigarette smoking, lifestyle factors, and microsatellite instability in colon tumors. J Natl Cancer Inst 92:1831-1836, 2000

22. Sinicrope FA, Foster NR, Yoon $\mathrm{HH}$, et al: Association of obesity with DNA mismatch repair status and clinical outcome in patients with stage II or III colon carcinoma participating in NCCTG and NSABP adjuvant chemotherapy trials. J Clin Oncol 30:406-412, 2012

23. Campbell PT, Jacobs ET, Ulrich $C M$, et al: Case-control study of overweight, obesity, and colorectal cancer risk, overall and by tumor microsatellite instability status. J Natl Cancer Inst 102:391-400, 2010

24. Helleman J, van Staveren IL, Dinjens WN, et al: Mismatch repair and treatment resistance in ovarian cancer. BMC Cancer 6:201, 2006

25. Kim S, Baron JA, Mott LA, et al: Aspirin may be more effective in preventing colorectal adenomas in patients with higher BMI (United States). Cancer Causes Control 17:1299-1304, 2006

26. Neill AS, Nagle CM, Protani MM, et al: Aspirin, nonsteroidal anti-inflammatory drugs, paracetamol and risk of endometrial cancer: A case-control study, systematic review and meta-analysis. Int J Cancer 132:1146-1155, 2013

27. Lassale $C$, Péneau $S$, Touvier M, et al: Validity of web-based self-reported weight and height: Results of the Nutrinet-Santé study. J Med Internet Res 15:e152, 2013

\section{Affiliations}

Mohammad Movahedi, Beheshti University of Medical Sciences, Tehran, Iran; Mohammad Movahedi and D. Timothy Bishop, University of Leeds, Leeds; Diana Eccles, University of Southampton, Southampton; D. Gareth Evans, St Mary's Hospital, Manchester; Eamonn R. Maher, University of Birmingham, Birmingham; Malcolm G. Dunlop, Western General Hospital, Edinburgh; Shirley V. Hodgson, St George's Hospital; Lucy Side, University College London; Huw J.W. Thomas, St Mark's Hospital, Imperial College, London; Patrick J. Morrison, Queens University Belfast, Belfast City Hospital Health and Social Care Trust, Belfast; Victoria Murday, Yorkhill Hospital, Glasgow; John Burn and John C. Mathers, Newcastle University, Newcastle upon Tyne, United Kingdom; Finlay Macrae, Royal Melbourne Hospital, Melbourne, Victoria; Rodney J. Scott, John Hunter Hospital, New Lambton, New South Wales, Australia; Jukka-Pekka Mecklin, Jyväskylä Central Hospital, Jyväskylä, Finland; Gabriela Moeslein, HELIOS St Josefs Hospital, Bochum-Linden, Germany; Sylviane Olschwang, Institut Paoli Calmettes, Marseille, France; Lucio Bertario, Istituto Nazionale per lo Studio e la Cura dei Tumori, Milan, Italy; Marie-Luise Bisgaard, University of Copenhagen, Hvidovre, Denmark; Judy W.C. Ho, Queen Mary Hospital, Hong Kong, Special Administrative Region, People's Republic of China; Annika Lindblom, Karolinska Institutet, Stockholm, Sweden; Jan Lubinski, International Hereditary Cancer Centre, Szczecin, Poland; Raj S. Ramesar, University of Cape Town, South Africa; and Hans F. Vasen, Netherlands Foundation of the Detection of Hereditary Tumours and Leiden University, Leiden, the Netherlands.

\section{GLOSSARY TERMS}

Lynch syndrome: hereditary nonpolyposis colorectal cancer (HNPCC). A cancer syndrome characterized by Henry T. Lynch in 1966, this genetic condition has a high risk of colon cancer as well as other cancers including endometrial, ovary, stomach, small intestine, hepatobiliary tract, upper urinary tract, brain, and skin.
Mismatch repair: one of four major pathways of DNA repair in mammalian cells. Mismatch repair recognizes and corrects errors in DNA replication leading to single base-pair mismatches or insertions/ deletions in small repetitive tracts of DNA known as microsatellites. 


\section{AUTHORS' DISCLOSURES OF POTENTIAL CONFLICTS OF INTEREST}

Obesity, Aspirin, and Risk of Colorectal Cancer in Carriers of Hereditary Colorectal Cancer: A Prospective Investigation in the CAPP2 Study

The following represents disclosure information provided by authors of this manuscript. All relationships are considered compensated. Relationships are self-held unless noted. I = Immediate Family Member, Inst = My Institution. Relationships may not relate to the subject matter of this manuscript. For more information about ASCO's conflict of interest policy, please refer to $w w w$.asco.org/rwc or jco.ascopubs.org/site/ifc.

\section{Mohammad Movahedi}

No relationship to disclose

\section{Timothy Bishop}

No relationship to disclose

\section{Finlay Macrae}

Research Funding: Pfizer, Bristol-Myers Squibb, Cellgene, AbbieVie, Glutagen, Janssen, Osidis, Actelion, CSIRO, Amgen

\section{Jukka-Pekka Mecklin}

No relationship to disclose

Gabriela Moeslein

Honoraria: Bayer Consultancy, Tillots Consultancy

Consulting or Advisory Role: Tillots Consultancy

\section{Sylviane Olschwang}

No relationship to disclose

\section{Diana Eccles}

Honoraria: AstraZeneca

Travel, Accommodations, Expenses: AstraZeneca

\section{Gareth Evans}

No relationship to disclose

\section{Eamonn R. Maher}

No relationship to disclose

\section{Lucio Bertario}

No relationship to disclose

\section{Marie-Luise Bisgaard}

Research Funding: Lundbeck

Malcolm G. Dunlop

No relationship to disclose

Judy W.C. Ho

Research Funding: Fresenius Kabi

\section{Shirley V. Hodgson}

No relationship to disclose

\section{Annika Lindblom}

No relationship to disclose

Jan Lubinski

No relationship to disclose

Patrick J. Morrison

No relationship to disclose

Victoria Murday

No relationship to disclose

Raj S. Ramesar

No relationship to disclose

Lucy Side

Travel, Accommodations, Expenses: Novartis

Rodney J. Scott

Consulting or Advisory Role: Merck Serono

Huw J.W. Thomas

No relationship to disclose

Hans F. Vasen

No relationship to disclose

John Burn

Employment: QuantuMDx

Leadership: QuantuMDx

Stock or Other Ownership: QuantuMDx

Honoraria: Bayer Pharma

Consulting or Advisory Role: AstraZeneca

Research Funding: Bayer Pharma

\section{John C. Mathers}

No relationship to disclose 


\section{Appendix}

Table A1. Outcomes From Previous Studies of Associations Between BMI and Colorectal Neoplasia in Patients With LS

\begin{tabular}{|c|c|c|c|c|c|c|}
\hline \multirow[b]{2}{*}{ Reference } & \multirow[b]{2}{*}{ Study Design } & \multirow[b]{2}{*}{ Outcome } & \multirow[b]{2}{*}{ Sex } & \multirow[b]{2}{*}{ BMI $\left(\mathrm{kg} / \mathrm{m}^{2}\right)$} & \multicolumn{2}{|c|}{ Risk Estimate $(95 \% \mathrm{Cl})$} \\
\hline & & & & & OR & HR \\
\hline Diergaarde et al* $\dagger$ & Case control & CRC & Both & $\begin{array}{l}<23.2 \\
>25.5\end{array}$ & $\begin{array}{c}1 \text { (referent) } \\
0.90 \text { (0.4 to } 1.8)\end{array}$ & \\
\hline Campbell et $a l^{8} \ddagger$ & Case control & $\mathrm{CRC}$ & $\begin{array}{l}\text { M } \\
\mathrm{F}\end{array}$ & $\begin{array}{l}18.5-24.99 \\
25-29.99 \\
\geq 30 \\
18.5-24.99 \\
25-29.99 \\
\geq 30\end{array}$ & $\begin{array}{c}1 \text { (referent) } \\
1.25 \text { (0.97 to } 1.61) \\
1.83(1.33 \text { to } 2.51) \\
1 \text { (referent) } \\
1.03(0.80 \text { to } 1.33) \\
0.85(0.62 \text { to } 1.16)\end{array}$ & \\
\hline Win et $\mathrm{al}^{9} \S \|$ & Retrospective & $\mathrm{CRC}$ & Both & $\begin{array}{l}<18.5 \\
18.5-24.99 \\
25.0-29.99 \\
\geq 30\end{array}$ & & $\begin{array}{l}1.04 \text { (0.00 to } 1.64) \\
1 \text { (referent) } \\
1.12 \text { (0.78 to } 1.62) \\
2.35(1.30 \text { to } 4.23)\end{array}$ \\
\hline \multirow[t]{2}{*}{ Botma et $\mathrm{al}^{5} \S$} & Prospective (incident cohort) & Adenomatous polyps & M & $\begin{array}{l}<25 \\
\geq 25 \\
<25 \\
\geq 25\end{array}$ & & $\begin{array}{c}1 \text { (referent) } \\
5.19 \text { (1.30 to } 20.80) \\
1 \text { (referent) } \\
0.78 \text { (0.20 to } 3.05)\end{array}$ \\
\hline & Prospective (prevalent cohort) & Adenomatous polyps & $\mathrm{M}$ & $\begin{array}{l}<25 \\
\geq 25 \\
<25 \\
\geq 25\end{array}$ & & $\begin{array}{c}1 \text { (referent) } \\
1.00 \text { (0.42 to } 2.38) \\
1 \text { (referent) } \\
0.91 \text { (0.29 to } 2.91)\end{array}$ \\
\hline $\begin{array}{l}\text { Abbreviations: BM } \\
\text { *Diergaarde B et al } \\
\text { †Both mismatch re } \\
\text { †Clinically defined } \\
\text { SKnown carriers of } \\
\text { \|Estimated from se }\end{array}$ & $\begin{array}{l}\text { dy mass index; CRC, colorectal } \\
\text { n Gastroenterol Hepatol 5:736-7 } \\
\text { gene mutation carriers ( } n=73 \text { ) } \\
\text { lial risk of cancer (according to } \\
\text { mline mutations in mismatch re } \\
\text { ported height and weight at app }\end{array}$ & $\begin{array}{l}\text { er; HR, hazard ratio; LS, } \\
007 \text {. } \\
\text { untested individuals su } \\
\text { erdam or revised Bethe } \\
\text { yenes. } \\
\text { nately age } 20 \text { years. }\end{array}$ & $\begin{array}{l}\text { ch syn } \\
\text { ted of } \\
\text { criteria }\end{array}$ & $\begin{array}{l}\text { e; OR, odds } \\
\text { S) LS ( } n=17 \\
\text { S). }\end{array}$ & & \\
\hline
\end{tabular}

